\title{
KRITIK DAN SYARAH HADITS
}

\author{
Darrotul Jannah \\ Fakultas Ilmu Tarbiyah dan Keguruan \\ Institut Agama Islam Negeri Syekh Nurjati Cirebon \\ Email: Jannah@gmail.com
}

\begin{abstract}
ABSTRAK
Sejak zaman Rasulullah pendidikan jasmani dan keterampilan telah ada,bahkan sangat dianjurkan oleh Rasulullah. Keterampilan yang dianjurkan Rasulullah semisal memanah, berkuda, lari, dan sebagainya. Hadis induk dari pembahasan tentang pendidikan jasmani dan keterampilan adalah riwayat anNasa'i no.hadis 3522 kemudian diperkuat oleh hadis-hadis lainnya, yaitu riwayat Imam Ahmad Bin Hanbal no.hadis 16683, riwayat Ahmad bin Hanbal no.hadis 16697, riwayat Imam Abu Daud no.hadis 2152, dan riwayat ad-Darimi no.hadis 2298. jalur dan kualitas rawi hadis tentang hadis di atas dapat diketahui semua rawi hadis melalui jalur sahabat Uqbah bin Amir dalam sunan Nasa'i no. Hadis 3522 dan dalam riwayat Ahmad no. Hadis 16683, Ahmad no. Hadis 16697 tersebut dinilai siqah, dan sunan Abu Daud no. Hadis 2152 Darimi no. Hadis 2298 juga dinilai siqah. serta tidak ada jarh (celaan) terhadap mereka shingga hadisnya dapat diterima oleh rawi-rawi lainnya.
\end{abstract}

Kata Kunci: Kritik dan Hadits 


\section{PENDAHULUAN}

Pendidikan Jasmani dan Keterampilan terdiri dari tiga kata yaitu: Pendidikan, Jasmani, dan Keterampilan. Pendidikan dapat diartikan sebagai proses perubahan sikap dan tata laku seseorang atau kelompok orang dalam usaha mendewasakan manusia melalui upaya pengajaran dan latihan; proses, perbuatan, cara mendidik. ${ }^{1}$ Sedangkan jasmani adalah tubuh: badan. ${ }^{2}$

Jasmani terbagi oleh beberapa struktur. Struktur jasmani memiliki daya atau energi yang menyumbangkan proses fisiknya. Energi ini lazimnya disebut dengan daya hidup ( Al-Hayah). Suatu tingkah laku dapat berwujud apabila struktur jasmani telah ditempati struktur ruh. ${ }^{3}$ Sedangkan keterampilan adalah kemampuan melakukan pola-pola tingkah laku yang kompleks dan tersusun rapi secara mulus dan sesuai dengan keadaan untuk mencapai hasil tertentu. ${ }^{4}$

Pada pembahasan Pendidikan jasmani dan keterampilan penulis mengambil dari hadis An-Nas'i no. Hadis 3522. Sebagai hadis pokok untuk pemahaman tentang pendidikan jasmani dan keterampilan. Selain itu ada hadis pendukung lainnya untuk memperkuat hadis tersebut. Sehingga dapat diketahui kualitas hadis an-Nasai tersebut.

\footnotetext{
${ }^{1}$ Dinas P \& K, kamus Besar Bahasa Indonesia, (Jakarta: Balai Pustaka, 2003). 204

${ }^{2} \mathrm{http}: / /$ www.artikata.com/arti-331498-jasmani.html diakses pada tanggal 20 november 2013.

${ }^{3}$ Abdul Mujib, Kepribadian dalam Psikologi Islam, ( Jakarta: PT Raja Grafindo Persada, 2006), 113-114

${ }^{4}$ Muhibbin Syah, Psikologi Pendidikan Suatu Pendekatan Baru, (Bandung: Remaja Rosdakarya, 1995). 118
} 


\section{PEMBAHASAN}

A. Hadis Pendidikan Jasmani dan Keterampilan Menurut Hadis

Sejak zaman Rasulullah pendidikan jasmani dan keterampilan telah ada,bahkan sangat dianjurkan oleh Rasulullah. Keterampilan yang dianjurkan Rasulullah semisal memanah, berkuda, lari, dan sebagainya. Seperti yang tertera dalam hadis yang diriwayatkan oleh An-Nasa'i.

Hadis Riwayat An-Nasa'i 3522.

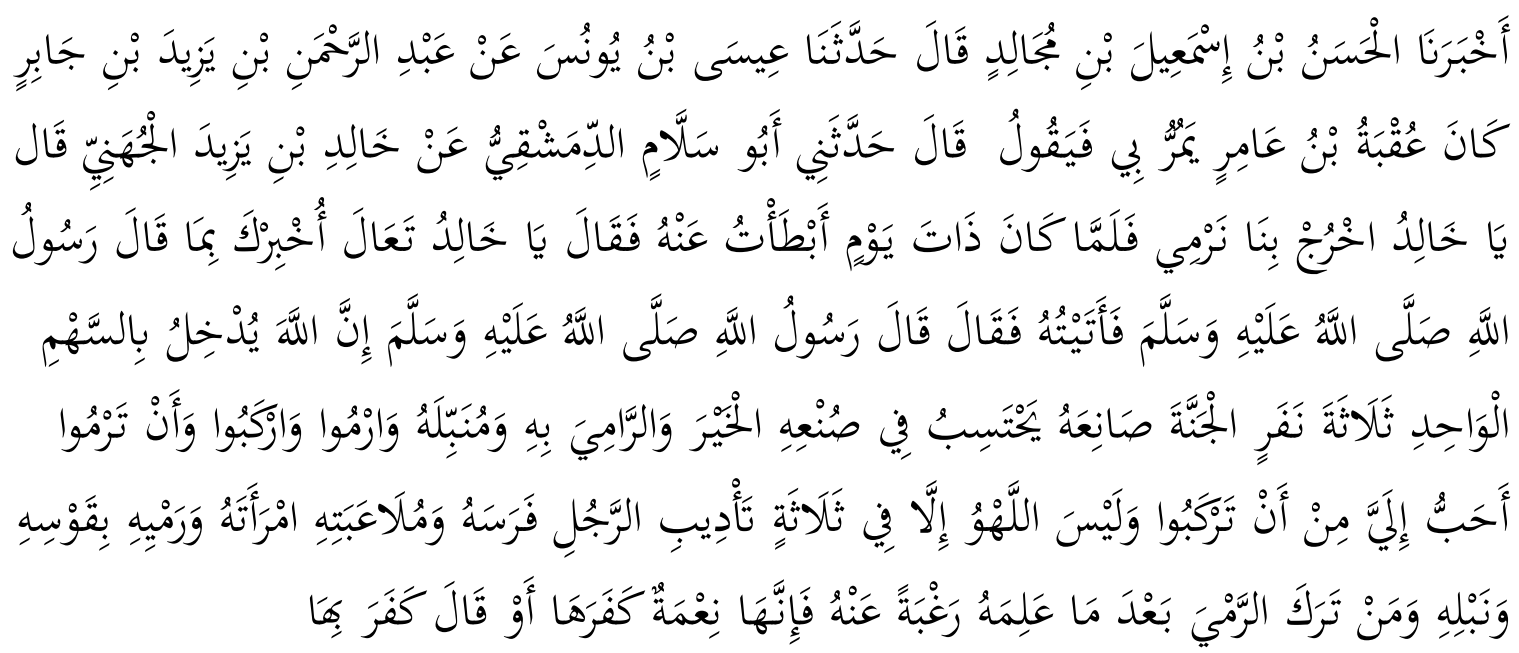

Telah mengabarkan kepada kami Al Hasan bin Isma'il bin Mujalid berkata; telah menceritakan kepada kami Isa bin Yunus dari 'Abdurrahman bin Yazid bin Jabir berkata; telah menceritakan kepadaku Abu Salam Ad Dimasyqi dari Khalid bin Yazid Al Juhani berkata; 'Uqbah bin 'Amir melewatiku dan berkata, "Wahai Khalid, keluarlah bersama kami untuk melempar." Kemudian pada suatu hari aku memperlambat jalan darinya, kemudian ia berkata, "Wahai Khalid, kemarilah. Aku kabarkan kepadamu apa yang telah disabdakan Rasulullah shallallahu 'alaihi wasallam." Kemudian aku datang kepadanya dan ia berkata, "Rasulullah shallallahu 'alaihi wasallam bersabda: "Sungguh, dengan satu anak panah Allah memasukkan 
tiga orang ke dalam Surga; yaitu pembuatnya yang dalam membuatnya mengharapkan kebaikan, orang yang memanah dan orang yang mengambilkan anak panah. Panah dan berkudalah, dan kalian memanah lebih aku sukai daripada kalian berkuda. Tidak ada hiburan kecuali dalam tiga hal; seorang laki-laki yang melatih kudanya, candaan seorang terhadap isterinya, dan lemparan anak panahnya. Dan barangsiapa yang tidak melempar setelah ia mengetahui ilmunya karena tidak menyenanginya, maka sesungguhnya hal itu adalah kenikmatan yang ia kufuri. ${ }^{5}$

Disamping itu ada hadis-hadis pendukung lainnya, yaitu hadis Ahmad Hanbali no.16683, Ahmad Hanbal no. 16697, Abu Daud no.2152, ad-Darimi no. 2298.

Riwayat Ahmad bin Hanbal no. 16683

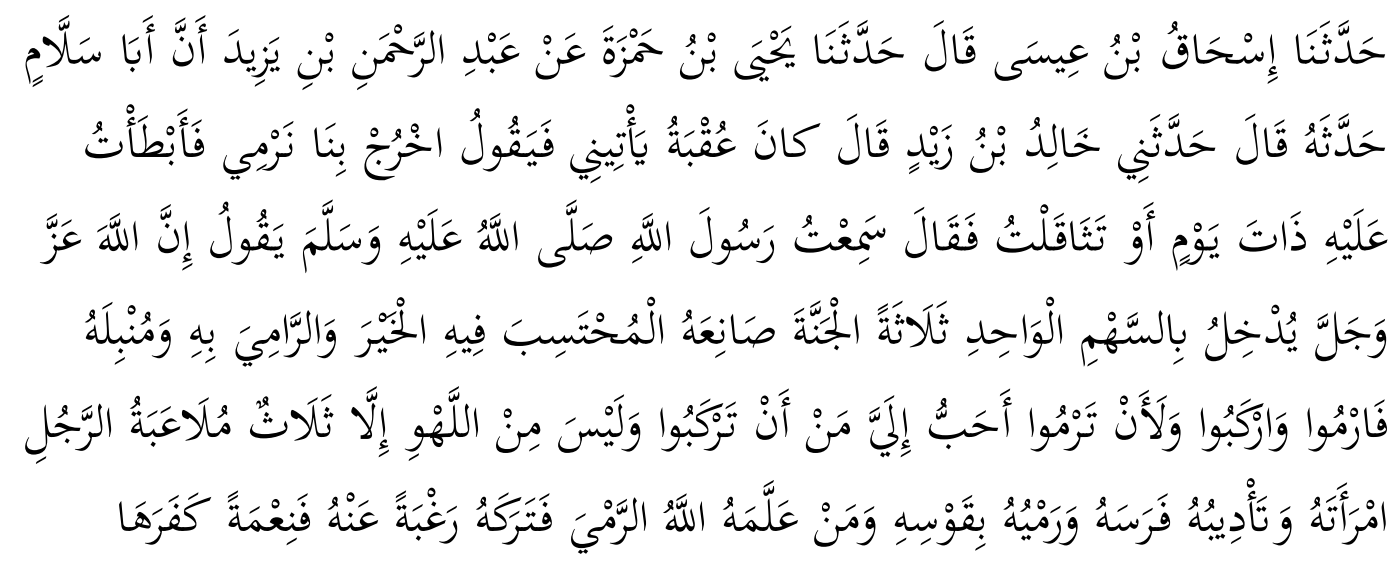

Telah menceritakan kepada kami Ishaq bin Isa dia berkata, Telah meneritakan kepada kami Yahya bin Hamzah dari Abdurrahman bin Yazid bahwa Abu Sallam menceritakan kepadanya, ia berkata; telah menceritakan kepadaku Khalid bin Zaid dia berkata, " Uqbah datang kepadaku dan berkata, "Keluarlah bersama kami untuk latihan memanah?" aku pun merasa berat enggan memenuhi ajakannya pada hari itu, ia lalu berkata, "Saya mendengar Rasulullah shallallahu 'alaihi wasallam bersabda: "Sesungguhnya Allah 'azza wajalla memasukkan tiga orang ke dalam surga lantaran satu anak panah. Yaitu, orang yang membuatnya dengan mengharap kebaikan, orang yang meluncurkannya, dan orang yang menyiapkannya. Karena itu, memanah dan menunggang kudalah kalian. Jika kalian benar-benar memanah, maka itu lebih saya sukai dari pada kalian latihan berkuda. Dan tidaklah termasuk sia-sia pada tiga hal ini; sendau gurau seseorang bersama isterinya, latihan berkuda dan melepaskan anak panah dari busurnya. Dan barangisapa diajarkan Allah cara memanah kemudian ia meninggalkannya karena enggan dan berpaling darinya, maka sungguh itu adalah nikmat yang telah dikufurinya."

${ }^{5}$ Lidwa Pustaka I-Software Kitab 9 Imam Hadis 
HR. Ahmad bin Hanbal no. 16697

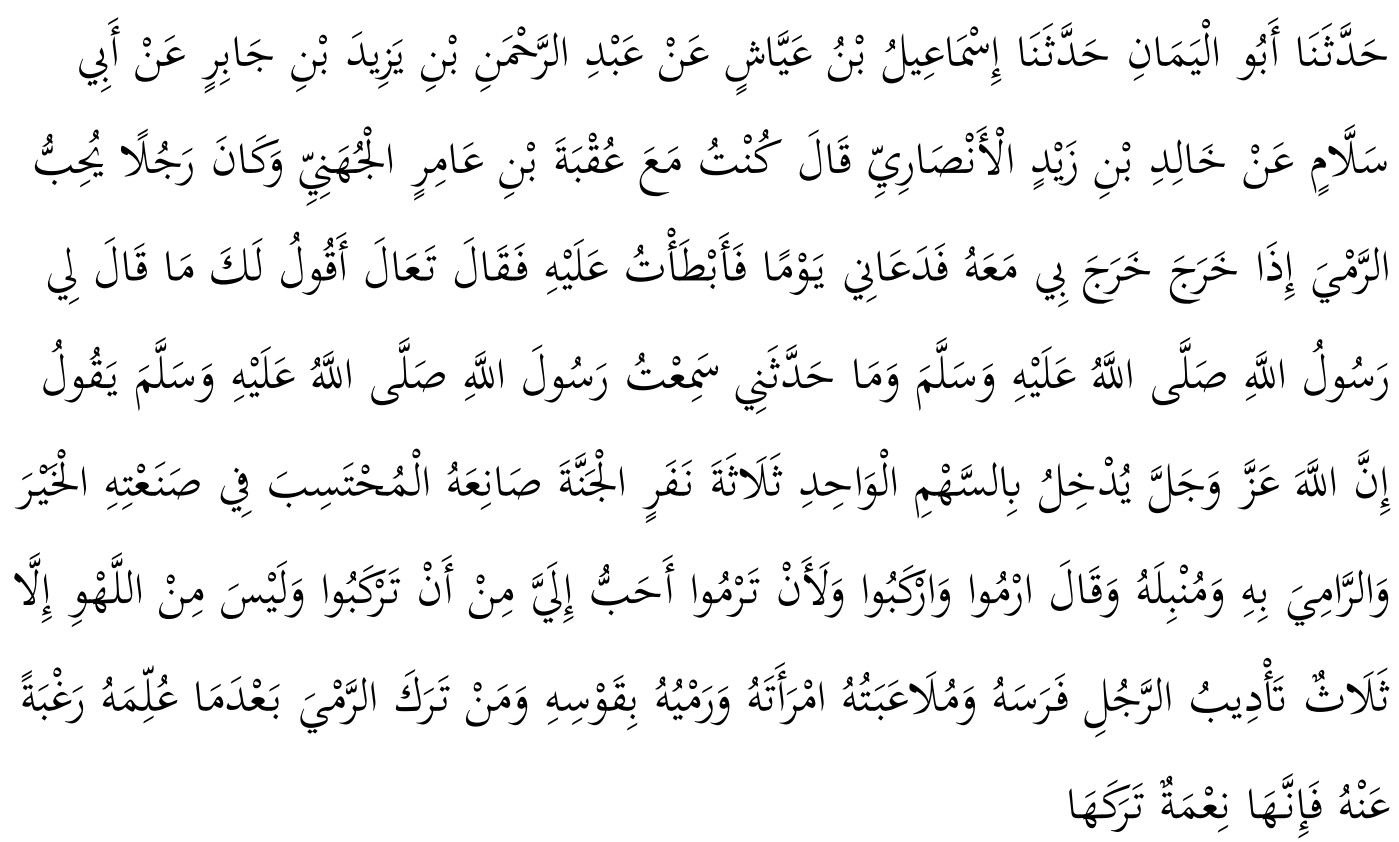

Telah menceritakan kepada kami Abul Yaman telah menceritkan kepada kami Isma'il bin Ayyasy dari Abdurrahman bin Yazid bin Jabir dari Abu Sallam dari Khalid bin Zaid Al Anshari dia berkata, "Saya pernah bersama Uqbah bin Amir Al Juhani, Ia adalah seorang laki-laki yang menyukai panahan. Jika ia keluar, maka ia selalu keluar bersamaku. Pada suatu hari ia mengajakku dan aku menolak ajakannya, maka ia berkata, "Kemarilah, saya akan mengatakan apa yang telah dikatakan dan diceritakan oleh Rasulullah shallallahu 'alaihi wasallam kepadaku, aku mendengar Rasulullah shallallahu 'alaihi wasallam bersabda: "Sesungguhnya Allah 'azza wajalla akan memasukkan tiga orang ke dalam surga lantaran satu anak panah. Yakni, orang yang membuatnya dengan berharap memperoleh kebaikan, orang yang memanahkannya dan orang yang menyiapkannya." Beliau juga bersabda: "Berlatihlah memanah dan berkuda. Dan jika kalian memilih memanah maka hal itu lebih aku sukai daripada berkuda. Dan tiga hal yang tidak termasuk sia-sia; latihan berkuda, senda gurau bersama isteri dan melepaskan panah dari busurnya. Barangisapa meninggalkan melempar panah setelah diajari karena berpaling darinya maka sungguh itu merupakan nikmat yang ia tinggalkan."

Riwayat Abu Daud no.2152

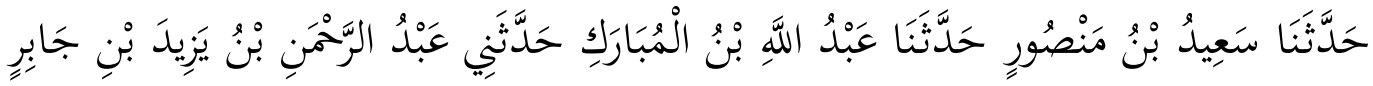

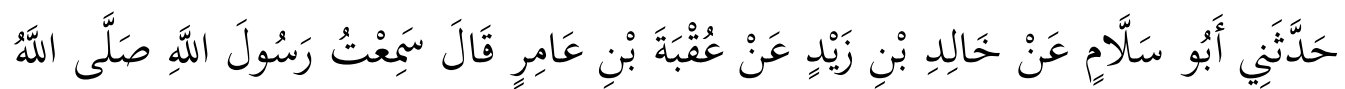

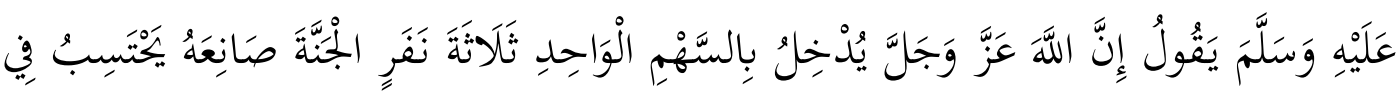




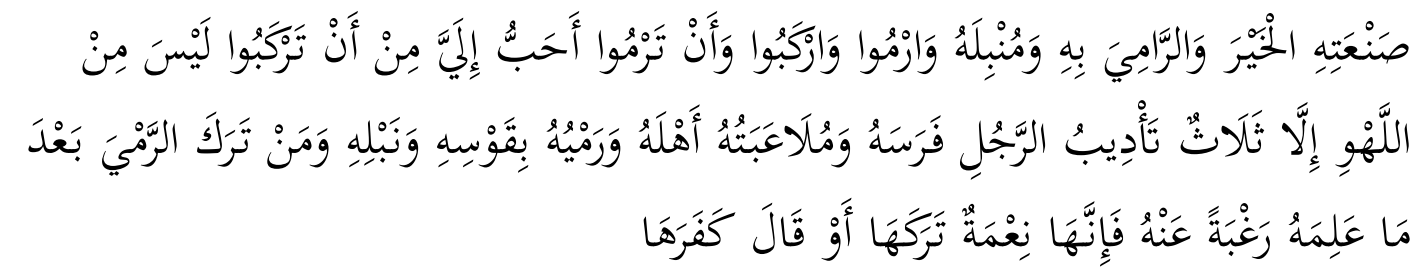

Telah menceritakan kepada kami Sa'id bin Manshur, telah menceritakan kepada kami Abdullah bin Al Mubarak, telah menceritakan kepadaku Abdurrahman bin Yazid bin Jabir, telah menceritakan kepadaku Abu Sallam, dari Khalid bin Zaid dari 'Uqbah, ia berkata; saya mendengar Rasulullah shallallahu 'alaihi wasallam berkata: "Sesungguhnya Allah memasukkan tiga orang ke dalam surga karena satu anak panah, yaitu: Pembuatnya yang menginginkan kebaikan dalam membuatnya, orang yang memanah dengannya, serta orang yang mengambilkan anak panah untuknya. Panah dan naiklah kuda, kalian memanah adalah lebih aku sukai daripada kalian menaiki kuda. Bukan termasuk hiburan (yang disunahkan) kecuali tiga perkara: seseorang melatih kudanya, bercanda dengan isterinya, dan memanah menggunakan busurnya serta anak panahnya. Dan barangsiapa yang meninggalkan memanah setelah ia mengetahuinya karena tidak senang kepadanya maka sesungguhnya hal tersebut adalah kenikmatan yang ia tinggalkan atau ia berkata: yang ia ingkari."

Riwayat Imam Ad-Darimi no.2298

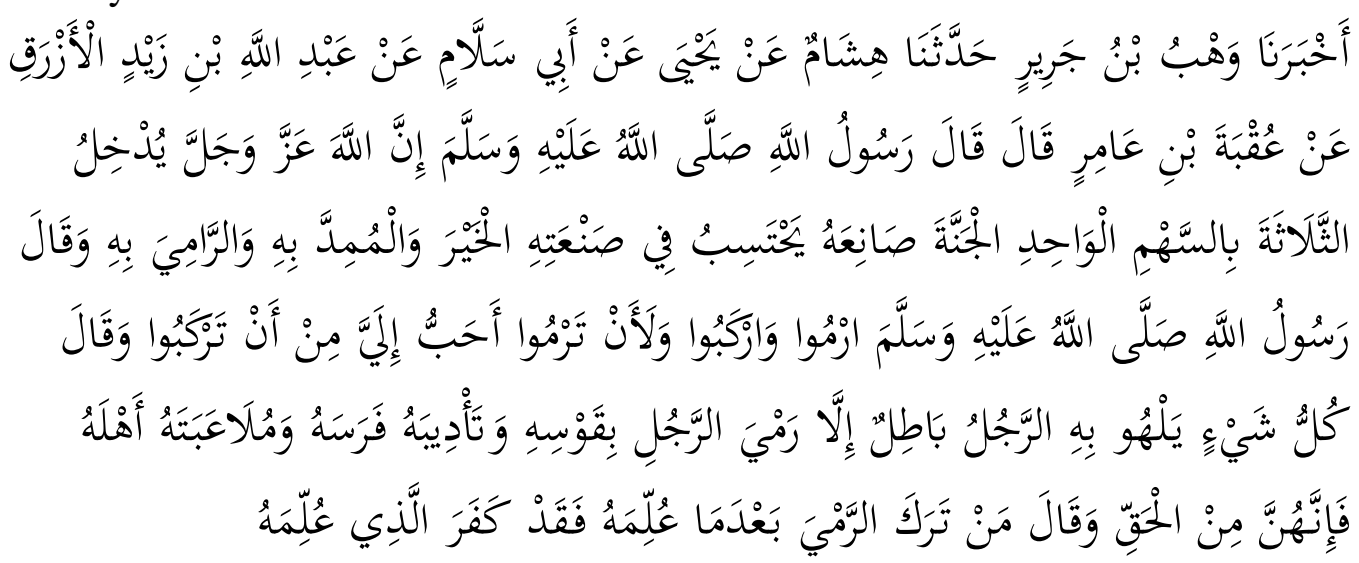

Telah mengabarkan kepada kami Wahb bin Jarir telah menceritakan kepada kami Hisyam dari Yahya dari Abu Salam dari Abdullah bin Zaid Al Azraq dari 'Uqbah bin 'Amir, ia berkata; Rasulullah shallallahu 'alaihi wasallam bersabda: "Sesungguhnya Allah 'azza wajalla memasukkan tiga orang ke dalam Surga karena anak panah, yaitu; pembuatnya yang mengharapkan kebaikan dalam membuatnya, orang yang mengambilkannya dan orang yang memanah degannya." Rasulullah shallallahu 'alaihi wasallam bersabda: "Panahlah dan naiklah kuda, sesungguhnya memanah lebih aku sukai daripada naik kuda." Dan beliau bersabda: "Segala hiburan yang dilakukan seseorang adalah sia-sia kecuali seorang laki-laki yang memanah dengan busur, mengajari kudanya, serta mencandai isterinya. Sesungguhnya ketiga hal itu adalah benar." Beliau juga 
bersabda; "Barangsiapa meninggalkan memanah setelah diajarkan kepadanya, sungguh ia telah ingkar terhadap sesuatu yang telah diajarkan kepadanya."

B. Skema sanad hadis tentang pendidikan jasmani dan keterampilan

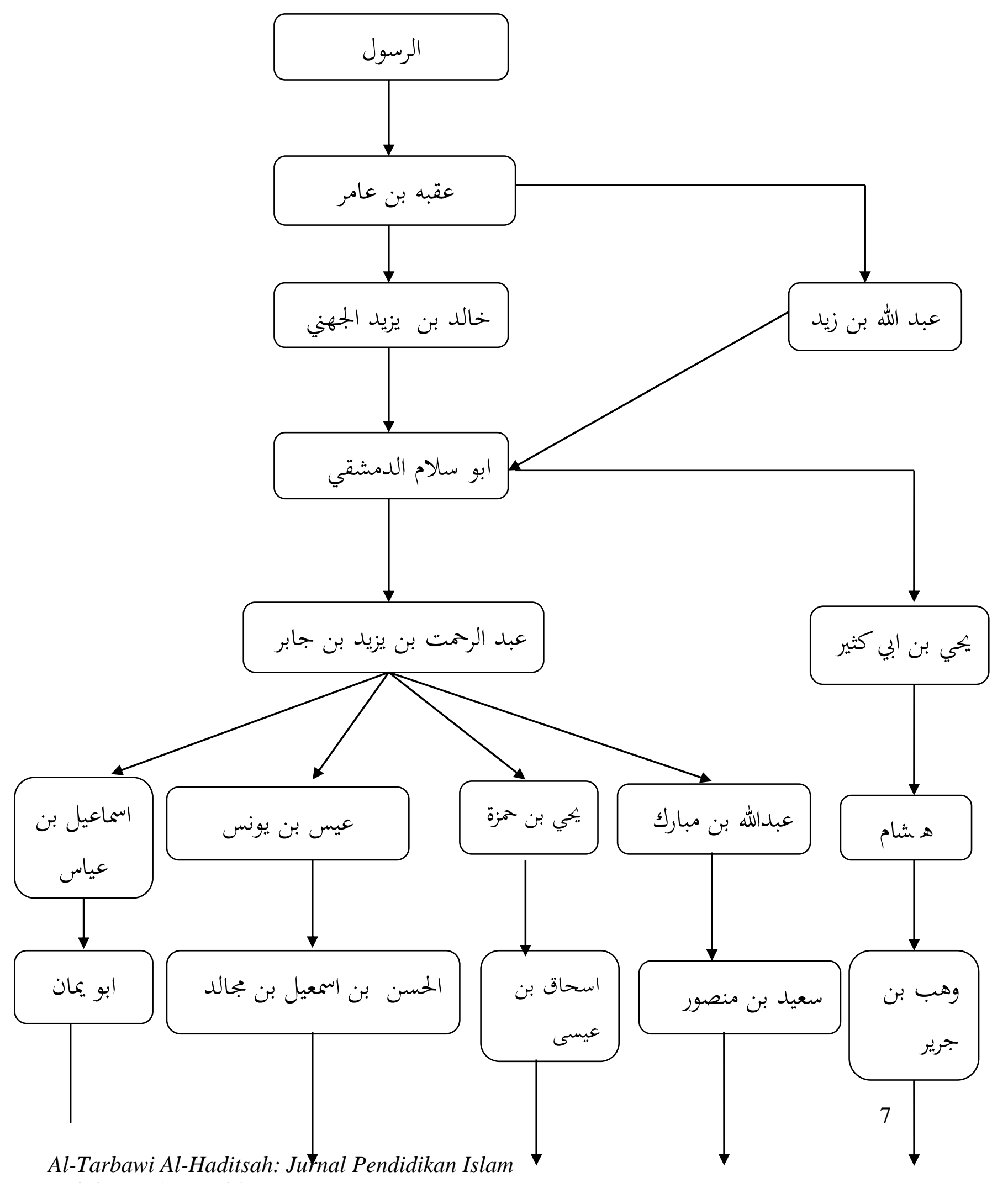

Vol. 2, No. 1, Juni 2017 

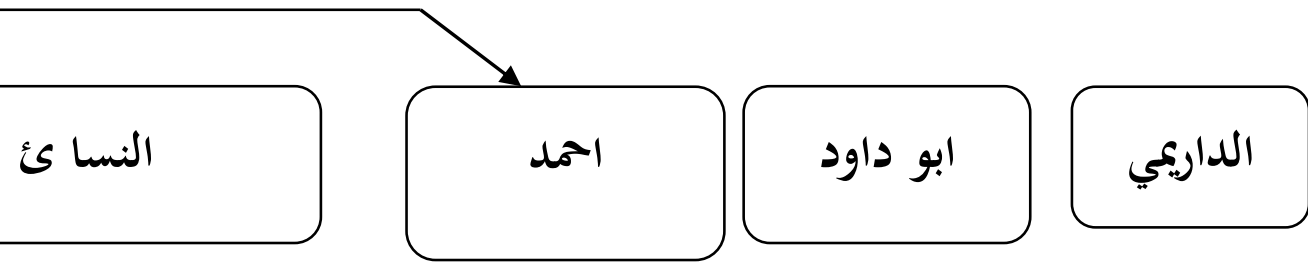

C. Riwayat hidup dan data-data rawi.

\section{Uqbah bin Amir bin Abbas}

Nama lengkap

: Uqbah bin Amir Bin Abbas bin 'Amru bin "Adiy bin 'Amru bin Rufa'ah bin Muda'ah Ibnu 'Adiy bin Ghaman bin Ruba'ah bin Rusdan bin Qais bin Juhainiyah AlJuhaini Abu Hammad.

Lahir

: Maru

Dari golongan

: Anshar

Kuniyah

: Abu Hammad

Kalangan

: sahabat

Wafat

$: 58 \mathrm{H}$

\begin{tabular}{|l|l|}
\hline ULAMA & \multicolumn{1}{c|}{ KOMENTAR } \\
\hline Ibnu Hibban & disebutkan dalam 'ats tsiqaat \\
\hline An Nasa'i & Tsiqah \\
\hline Ibnu Hajar al 'Asqalani & Tsiqah \\
\hline Adz Dzahabi & Tsiqah \\
\hline
\end{tabular}

Uqbah adalah seorang ahli dalam Ilmu Faraidh, bacaan al-Qur'annya paling indah dan seorang panglima perang yang ahli dalam hal memanah. Beliau mendapat julukan "Radif Rasulillah” (boncengan Rasulullah) karena hampir selalu mendampingi Rasulullah kemanapun beliau pergi. Uqbah meninggal dunia di bukit al-Muqaththam tahun $58 \mathrm{H}$, dan salah satu warisan peninggalannya adalah busur panah.

\section{Khalid bin Yazid}

Berasal dari kalangan Tabi'in pertengahan. Nama lengkapnya adalah Khalid bin Yazid Al-Juhani.

\begin{tabular}{|l|l|}
\hline \multicolumn{1}{|c|}{ ULAMA } & \multicolumn{1}{c|}{ KOMENTAR } \\
\hline Ibnu Hibban & mentsiqahkannya \\
\hline
\end{tabular}

\section{Abu Salam Ad-Dimasyqi}


Berasal dari kalangan Tabi'in (kalangan biasa)dengan kuniyah Abu Sallam dan menghabiskan masa hidup di syam.

\begin{tabular}{|l|l|}
\hline \multicolumn{1}{|c|}{ ULAMA } & \multicolumn{1}{c|}{ KOMENTAR } \\
\hline \multicolumn{1}{|c|}{ Al 'Ajli } & Tsiqah \\
\hline Ibnu Hibban & disebutkan dalam 'ats tsiqaat \\
\hline Ibnu Hajar al 'Asqalani & Tsiqah \\
\hline
\end{tabular}

\section{Abdur Rahman bin Yazid bin Jabir}

Nama Lengkap $\quad$ : Abdur Rahman bin Yazid bin Jabir

Kalangan : Tabi'ut Tabi'in kalangan tua

Kuniyah : Abu 'Utbah

Negeri semasa hidup : Syam

Wafat : $154 \mathrm{H}$

\begin{tabular}{|l|l|}
\hline \multicolumn{1}{|c|}{ ULAMA } & \multicolumn{1}{c|}{ KOMENTAR } \\
\hline Ahmad bin Hambal & laisa bihi ba`s \\
\hline Yahya bin Ma'in & Tsiqah \\
\hline An Nasa'i & Tsiqah \\
\hline Ya'kub bin Sufyan & Tsiqah \\
\hline
\end{tabular}

\section{Isa bin Yunus Abi Ishaq}

Berasal dari kalangan Tabi'ut Tabi'in kalangan pertengahan dengan Abu

'Amru dan menghabiskan masa hidup di kufah sebelum wafat pada tahun $187 \mathrm{H}$.

\begin{tabular}{|l|l|}
\hline \multicolumn{1}{|c|}{ ULAMA } & \multicolumn{1}{c|}{ KOMENTAR } \\
\hline Ahmad bin Hambal & Tsiqah \\
\hline Abu Hatim & Tsiqah \\
\hline An Nasa'i & Tsiqah \\
\hline Yahya bin Ma'in & Tsiqah \\
\hline
\end{tabular}

6. Al-Hasan bin Ismail bin Sulaiman bin Mujalid

Nama Lengkap $\quad$ : Isa bin Yunus bin Abi Ishaq

Kalangan $\quad$ : Tabi'ut Tabi'in kalangan pertengahan

Kuniyah : Abnu 'Amru

Negeri semasa hidup : Kufah

Wafat $\quad: 187 \mathrm{H}$

\begin{tabular}{|l|l|}
\hline \multicolumn{1}{|c|}{ ULAMA } & \multicolumn{1}{c|}{ KOMENTAR } \\
\hline Ibnu Hibban & disebutkan dalam 'ats tsiqaat \\
\hline An Nasa'i & Tsiqah \\
\hline Ibnu Hajar & al 'Asqalani Tsiqah \\
\hline
\end{tabular}


Jalur kedua adalah riwayat Ahmad no. 16683, rawi pertama sampai keempat sama dengan riwayat Nasa'i, sedangkan rawi lainnya adalah sebagai berikut.

\section{Yahya bin Hamzah bin Waqid}

Berasal dari kalangan Tabi'ut Tabi'in kalangan pertengahan dengan kuniyah Abu Abdur Rahman dan menghabiskan masa hidup di Syam sebelum wafat pada tahun $183 \mathrm{H}$.

\begin{tabular}{|l|l|}
\hline \multicolumn{1}{|c|}{ ULAMA } & \multicolumn{1}{c|}{ KOMENTAR } \\
\hline Ahmad bin Hambal & laisa bihi ba`s \\
\hline Yahya bin Ma'in & Tsiqah \\
\hline Abu Hatim & Shaduuq \\
\hline An Nasa'i & Tsiqah \\
\hline
\end{tabular}

\section{Ishaq bin Isa bin Najih}

Berasal dari kalangan Tabi'ut Tabi'in kalangan biasa dengan kuniyah Abu Ya'qub dan menghabiskan masa hidup di Adzanah sebelum wafat pada tahun $215 \mathrm{H}$.

\begin{tabular}{|l|l|}
\hline \multicolumn{1}{|c|}{ ULAMA } & \multicolumn{1}{c|}{ KOMENTAR } \\
\hline Al Bukhari & Masyhurul Hadits \\
\hline Ibnu Hibban & disebutkan dalam 'ats tsiqaat \\
\hline Ibnu Hajar al 'Asqalani & Shaduuq \\
\hline Adz Dzahabi & Tsiqah \\
\hline
\end{tabular}

Jalur ketiga adalah riwayat Ahmad no. 16697, rawi pertama sampai keempat sama dengan riwayat Nasa'i, sedangkan rawi lainnya adalah sebagai berikut.

\section{Ismail bin Ayyas bin Sulaim}

$\begin{array}{ll}\text { Nama Lengkap } & : \text { Isma'il bin 'Ayyasy bin Sulaim } \\ \text { Kalangan } & : \text { Tabi'ut Tabi'in kalangan pertengahan } \\ \text { Kuniyah } & : \text { Abu 'Utbah } \\ \text { Negeri semasa hidup } & : \text { Syam } \\ \text { Wafat } & : 181 \mathrm{H}\end{array}$




\begin{tabular}{|l|l|}
\hline \multicolumn{1}{|c|}{ ULAMA } & \multicolumn{1}{|c|}{ KOMENTAR } \\
\hline Ahmad bin Hambal & Husnu riwayatihi 'an asy Syamiyyin \\
\hline Yahya bin Ma'in & Laisa bihi ba`s fi ahli asy Syam \\
\hline Ali bin Al Madini & $\begin{array}{l}\text { Dia mentsiqahkannya pada orang-orang Syam dan } \\
\text { mendhaifkannya pada yang lainnya }\end{array}$ \\
\hline At Tirmidzi & Dishahihkan selain dari hadits ahli Syam \\
\hline
\end{tabular}

\section{Al-Hakam bin Nafi'}

$\begin{array}{ll}\text { Nama Lengkap } & : \text { Al Hakam bin Nafi' } \\ \text { Kalangan } & : \text { Tabi'ul Atba' kalangan tua } \\ \text { Kuniyah } & \text { : Abu Al Yaman } \\ \text { Negeri semasa hidup : Syam } \\ \text { Wafat }\end{array}$

\begin{tabular}{|l|l|}
\hline \multicolumn{1}{|c|}{ ULAMA } & \multicolumn{1}{c|}{ KOMENTAR } \\
\hline Yahya bin Ma'in & Tsiqah \\
\hline Abu Hatim Ar Rozy & Tsiqah Shaduuq \\
\hline Al 'Ajli & la ba`sa bih \\
\hline Ibnu Hibban & disebutkan dalam 'ats tsiqaat \\
\hline
\end{tabular}

Jalur keempat adalah riwayat Abu Daud no.2152. rawi pertama dan keempat sama dengan riwayat nasa'i no. 3522, dan rawi yang lainnya adalah sebagai berikut:

\section{Abdullah bin Al-Mubarak bin Wadlih}

Nama Lengkap $\quad$ : Abdullah bin Al Mubarak bin Wadlih

Kalangan : Tabi'ut Tabi'in kalangan pertengahan

Kuniyah : Abu 'Abdur Rahman

Negeri semasa hidup : Himash

Wafat $\quad: 181 \mathrm{H}$

\begin{tabular}{|l|l|}
\hline \multicolumn{1}{|c|}{ ULAMA } & \multicolumn{1}{c|}{ KOMENTAR } \\
\hline Ahmad bin Hambal & Hafizh \\
\hline Ibnul Madini & Tsiqah \\
\hline Yahya bin Ma'in & tsiqah tsabat \\
\hline Abu Hatim & tsiqah imam \\
\hline
\end{tabular}


2. Sa'id bin Manshur bin Syu'bah

Nama Lengkap : : Sa'id bin Manshur bin Syu'bah

Kalangan : Tabi'ul Atba' kalangan tua

Kuniyah : Abu 'Utsman

Negeri semasa hidup : Marur Rawdz

Wafat : $227 \mathrm{H}$

\begin{tabular}{|l|l|}
\hline \multicolumn{1}{|c|}{ ULAMA } & \multicolumn{1}{c|}{ KOMENTAR } \\
\hline Muhammad bin Sa'd & Tsiqah \\
\hline Abu Hatim Ar Rozy & Tsiqah Tsabat \\
\hline Adz Dzahabi & Alhafidz \\
\hline
\end{tabular}

Jalur kelima adalah riwayat Darimi no. 2298, rawinya adalah Uqbah bin Amir bin Abbas,dan selanjutya adalah:

\section{Abdullah bin zaid}

Berasal dari kalangan Tabi'in kalangan biasa. Ibnu Hajar Al-Asqalani menilai maqbul, sedangkan oleh Ibnu Hibban disebutkan dalam as-siqaat.

\begin{tabular}{|l|l|}
\hline \multicolumn{1}{|c|}{ ULAMA } & \multicolumn{1}{c|}{ KOMENTAR } \\
\hline Ibnu Hibban & disebutkan dalam 'ats tsiqaat \\
\hline Ibnu Hajar Al Atsqalani & maqbul \\
\hline
\end{tabular}

\section{Abu salam ad-Dimasyqi}

3. Yahya bin Abi Katsir

Nama Lengkap $\quad$ : Yahya bin Abi Katsir Shalih bin Al Mutawakkil

Kalangan : Tabi'in kalangan biasa

Kuniyah : Abu Nashr

Negeri semasa hidup : Yamamah

Wafat $\quad: 132 \mathrm{H}$

\begin{tabular}{|l|l|}
\hline \multicolumn{1}{|c|}{ ULAMA } & \multicolumn{1}{c|}{ KOMENTAR } \\
\hline Al 'Ajli & Tsiqah \\
\hline
\end{tabular}




\begin{tabular}{|l|l|}
\hline Abu Hatim & Tsiqah \\
\hline Ibnu Hibban & disebutkan dalam 'ats tsiqaat \\
\hline Ibnu Hajar al 'Asqalani & tsiqah tsabat \\
\hline Adz Dzahabi & seorang tokoh \\
\hline
\end{tabular}

\section{Hisyam bin Abi Abdullah Saubar}

Nama Lengkap : : Hisyam bin Abi 'Abdullah Sanbar

Kalangan : : Tabi'in kalangan pertengahan

Kuniyah : Abu Bakar

Negeri semasa hidup : Bashrah

Wafat $\quad: 154 \mathrm{H}$

\begin{tabular}{|l|l|}
\hline \multicolumn{1}{|c|}{ ULAMA } & \multicolumn{1}{c|}{ KOMENTAR } \\
\hline Al 'Ajli & Tsiqah \\
\hline Ibnu Sa'd & tsiqah tsabat \\
\hline Ibnu Hibban & disebutkan dalam 'ats tsiqaat \\
\hline Ibnu Hajar al 'Asqalani & tsiqah tsabat \\
\hline Adz Dzahabi & Hafizh \\
\hline
\end{tabular}

\section{Wahab bin Jarir bin Hazim}

Nama Lengkap : : Wahab bin Jarir bin Hazim

Kalangan : Tabi'ut Tabi'in kalangan biasa

Kuniyah : Abu Al 'Abbas

Negeri semasa hidup : Bashrah

Wafat : $206 \mathrm{H}$

\begin{tabular}{|l|l|}
\hline \multicolumn{1}{|c|}{ ULAMA } & \multicolumn{1}{c|}{ KOMENTAR } \\
\hline Yahya bin Ma'in & Tsiqah \\
\hline Abu Hatim & Shaduuq \\
\hline An Nasa'i & laisa bihi ba`s \\
\hline Ibnu Hibban & disebutkan dalam 'ats tsiqaat \\
\hline Al 'Ajli & Tsiqah \\
\hline Ibnu Sa'd & Tsiqah \\
\hline
\end{tabular}

Kriteria otensititas dan orisinilitas hadis menurut para ulama hadis ada lima yaitu:

a. Sanadnya bersambung (Muttasil)

b. Seluruh perawinya bersifat 'Adil ('Adil menyangkut integritas pribadi dan keteguhan agamanya yang benar-benar muncul dari nurani sehingga dirinya 
takut melakukan kebohongan) dan Dhabit (dikenal memiliki daya hafal yang kuat $)^{6}$

c. Sanad dan matannya terhindar dari kejanggalan $\left(\right.$ Syadz) dan cacat $(\text { illat })^{7}$

Berdasarkan data mengenai jalur dan kualitas rawi hadis tentang hadis di atas dapat diketahui semua rawi hadis melalui jalur sahabat Uqbah bin Amir dalam sunan Nasa'i no. Hadis 3522 dan hadis-hadis pendukung lainnya dinilai siqah serta tidak ada celaan (jarh) terhadap mereka shingga hadisnya dapat diterima..

\section{PENUTUP}

\section{A. Kesimpulan}

Hadis induk dari pembahasan tentang pendidikan jasmani dan keterampilan adalah riwayat an-Nasa'i no.hadis 3522 kemudian diperkuat oleh hadis-hadis lainnya, yaitu riwayat Imam Ahmad Bin Hanbal no.hadis 16683, riwayat Ahmad bin Hanbal no.hadis 16697, riwayat Imam Abu Daud no.hadis 2152, dan riwayat ad-Darimi no.hadis 2298.

Dari skema hadis tentang pendidikan jasmani dan keterampilan terdapat lima jalur sanad. Setiap perawi mempunyai ketersambungan dengan perawi yang lain. Dan dari kelima jalur sanad tersebut/ semua hadis tersebut diriwayatkan

${ }^{6}$ Mahmud At-Tahhan, Metode Tahrij dan Penelitian Sanad Hadis, ( Surabaya: PT Bina Ilmu Offset, 2005). 100

${ }^{7}$ Salahudin ibn Ahmadal-Adlabi, Metodologi Kritik Matan Hadis terj. M. Qadirun dan Ahmad Musyafiq ( Jakarta: Gaya Media Pertama, 2004). 17-18 
hanya melalui satu jalur sahabat yaitu Uqbah bin Amir Al-Juhaini. Sehingga kelima hadis ini ada ketersambungan perawi.

Berdasarkan data mengenai jalur dan kualitas rawi hadis tentang hadis di atas dapat diketahui semua rawi hadis melalui jalur sahabat Uqbah bin Amir dalam sunan Nasa'i no. Hadis 3522 dan dalam riwayat Ahmad no. Hadis 16683, Ahmad no. Hadis 16697 tersebut dinilai siqah, dan sunan Abu Daud no. Hadis 2152 Darimi no. Hadis 2298 juga dinilai siqah. serta tidak ada jarh (celaan) terhadap mereka shingga hadisnya dapat diterima oleh rawi-rawi lainnya.

\section{DAFTAR PUSTAKA}

At-Tahhan, Mahmud, Metode Tahrij dan Penelitian Sanad Hadis, Surabaya: PT Bina Ilmu Offset, 2005.

Dinas P \& K, kamus Besar Bahasa Indonesia, Jakarta: Balai Pustaka, 2003.

http://www.artikata.com/arti-331498-jasmani.html diakses pada tanggal 20 november 2013.

Lidwa Pustaka I-Software Kitab 9 Imam Hadis 
Mujib, Abdul, Kepribadian dalam Psikologi Islam, Jakarta: PT Raja Grafindo Persada, 2006.

Salahudin ibn Ahmadal-Adlabi, Metodologi Kritik Matan Hadis terj. M. Qadirun dan Ahmad Musyafiq. Jakarta: Gaya Media Pertama, 2004.

Syah, Muhibbin, Psikologi Pendidikan Suatu Pendekatan Baru, Bandung: Remaja Rosdakarya, 1995 